\title{
Bioavailability and Immunity Response in Broiler Breeders on Organically Complexed Zinc Supplementation
}

\author{
Neeta Soni, Sumanta Kumar Mishra ${ }^{*}$, Rajakishore Swain, Abinash Das, Biswal Chichilichi, \\ Kamdev Sethy
}

Department of Animal Nutrition, College of Veterinary Science and Animal Husbandry, Orissa University of Agriculture and Technology, Bhubaneswar, India.

Email: *sumantkmishra@gmail.com

Received September $17^{\text {th }}, 2013$; revised October $17^{\text {th }}, 2013$; accepted October $24^{\text {th }}, 2013$

Copyright (C) 2013 Neeta Soni et al. This is an open access article distributed under the Creative Commons Attribution License, which permits unrestricted use, distribution, and reproduction in any medium, provided the original work is properly cited. In accordance of the Creative Commons Attribution License all Copyrights (C) 2013 are reserved for SCIRP and the owner of the intellectual property Neeta Soni et al. All Copyright (C) 2013 are guarded by law and by SCIRP as a guardian.

\begin{abstract}
Two hundred and sixty four broiler breeder hens of 32 weeks of age were distributed randomly in four dietary treatments. The dietary treatments were $\mathrm{T}_{0}$ : Broiler breeder ration containing $40 \mathrm{ppm}$ zinc (basal $29.8 \mathrm{ppm}+10.2 \mathrm{ppm}$ inorganic zinc), $\mathrm{T}_{1}: \mathrm{T}_{0}+$ organic zinc (zinc methionine) @ $20 \mathrm{ppm}, \mathrm{T}_{2}: \mathrm{T}_{0}+$ organic zinc @ $40 \mathrm{ppm}$ and $\mathrm{T}_{3}: \mathrm{T}_{0}+$ organic zinc @ 60 ppm. The experiment was continued from 32 to 48 weeks of age. At 48 weeks, the weight of lymphoid organs, zinc levels in organs and immunity response were determined. The faecal zinc level was determined at monthly interval. The weight lymphoid organs of different treatment groups (both organic and inorganic zinc fed groups) of the broiler breeders did not differ significantly $(\mathrm{P}>0.05)$. The cellular immune response of breeder birds to PHA-P was significantly $(\mathrm{P}<0.05)$ higher in group $\mathrm{T}_{3}$ than the rest of treated groups. The antibody titre to SRBC differed among the treated groups. The zinc content of serum of broiler breeders of all the groups did not differ significantly $(\mathrm{P}>0.05)$ in all the periods of study. Zinc content in liver and tibia of broiler breeders in different dietary treatments of zinc differed significantly $(\mathrm{P}<0.05)$ with higher levels were obtained on increasing zinc concentration in the diet. The zinc level in the spleen and kidney of the broiler breeders in different dietary treatments did not differ significantly $(\mathrm{P}>$ 0.05). The average zinc content in the faeces of broiler breeder during 35 to 43 week of age did not differ significantly $(P>0.05)$ among the treated groups. At 48 weeks of age, zinc content of the faeces of $T_{3}$ was found to be significantly $(\mathrm{P}<0.05)$ higher than the rest of treated groups. Similarly, during the overall experimental period analysis, it was found that zinc levels in the faeces of $T_{2}$ and $T_{3}$ were significantly $(P<0.05)$ higher than $T_{1}$ and $T_{0}$.
\end{abstract}

Keywords: Organic Zinc; Immunity; Bioavailability; Broiler Breeders

\section{Introduction}

Zinc impacts immunity in poultry [1]. Zinc deficiency has been shown to decrease cellular immunity [2], thymus [3] and spleen development [4]. Zinc is important for proper disease resistance and its deficiency has resulted in bacteremia [5], parasitic infections [6] and alteration in high-density lipoprotein cholesterol [7]. Znmethionine provides a source of zinc with greater biological availability than zinc from inorganic sources. Gill (1997) [8] reported that chelated (organic) minerals are more biologically available in animal digestive system than inorganic minerals and that perhaps resulted in less

${ }^{*}$ Corresponding author. mineral excretion and pollution of the environment. Today, large scale commercial livestock production system has given rise to many environmental concerns, since excess mineral concentrations in the manure can lead to mineral depositions that exceed crop nutrient requirement [9]. According to [10] and the opinion of Scientific Committee for Animal Nutrition on use of zinc in feeding stuffs, a clear indication of biological activity of zinc is: the content of this element in liver, melethionine activity, accumulation of zinc in the bones and levels of zinc in blood serum are the method of estimation of availability of this element in live animals. Considering the higher bioavailability of organic zinc [11] the experiment was planned to study the effect of organic zinc 
supplementation in broiler breeder birds on bioavailability and immune response.

\section{Materials and Methods}

\subsection{Selection and Management of Experimental Birds}

Female broiler breeder birds of synthetic dam line, maintained under All India Coordinated Research Network Project on "Poultry Breeding" were selected for the study. A total of two hundred and sixty four broiler breeder hens of 32 weeks of age were distributed randomly in four dietary treatments with three replicate per treatment. The hens were selected on the basis of their body weight and egg production. The hens were maintained in individual layer cages. Experimental diets were offered@150 g/bird/day throughout the experimental period. The hens were provided 24 hours free access to clean drinking water. The experiment continued for a period of sixteen weeks i.e. 32 to 48 weeks of age of the hens. A basal diet was prepared to meet the nutrient requirement of broiler breeders [12]. The ingredient composition and proximate composition of the basal diet is given in Table 1. The basal diet was analyzed for proximate composition as per [13].

\subsection{Dietary Treatments}

The dietary treatments of the experiment were: $T_{0}$ :
Broiler breeder ration containing $40 \mathrm{ppm}$ zinc (basal 29.8 $\mathrm{ppm}+10.2 \mathrm{ppm}$ inorganic zinc supplementation in form of $\left.\mathrm{ZnSO}_{4}\right), \mathrm{T}_{1}: \mathrm{T}_{0}+$ Supplementation of organic zinc (zinc methionine)@20 ppm in the broiler breeder ration, $\mathrm{T}_{2}: \mathrm{T}_{0}+$ Supplementation of organic zinc @ 40 ppm in the broiler breeder ration and $\mathrm{T}_{3}: \mathrm{T}_{0}+$ Supplementation of organic zinc @ 60 ppm in the broiler breeder ration.

\subsection{Collection and Processing of Experimental Samples}

At the end of the experimental period (48 weeks of age), three birds were randomly chosen from each replicate and slaughtered for collection of liver, spleen and kidney. The birds were kept off feed overnight before bleeding and only water was provided. The live weight of the birds were recorded as pre slaughter weight. The broiler birds were bled by modified Kosher's method [14]. Liver, spleen, bursa of fabricus and kidney were weighed in a top pan electric balance. Both the tibia bones were removed from the slaughter birds. The tibia bones were pressure cooked in deionised water for 15 minutes, cleaned off all tissues and dried in an oven for 72 hours until constant weight. Then the tibia bones were extracted in petroleum ether for 72 hours to remove fat and dried for 24 hours in $105^{\circ} \mathrm{C}$. The collected liver, kidney and spleen samples were oven dried at $100^{\circ} \mathrm{C}$ for 24 hours and finely grounded. The zinc content in the liver, kidney, bursa and spleen samples were determined by

Table 1. Ingredient and proximate composition of breeder basal diet.

\begin{tabular}{|c|c|c|c|}
\hline Ingredients & Percentage & Proximate composition & Percentage on DM basis \\
\hline Maize & 60.00 & Moisture & 9.17 \\
\hline Soyabean meal & 19.50 & Crude protein & 16.08 \\
\hline De oiled rice bran & 12.00 & Ether extract & 4.20 \\
\hline Mineral mixture ${ }^{\#}$ & 3.00 & Crude fibre & 4.82 \\
\hline Oyster shell meal & 5.00 & Total ash & 10.61 \\
\hline Common salt & 0.30 & Acid insoluble ash & 2.54 \\
\hline L-lysine & 0.03 & Nitrogen free extract ${ }^{*}$ & 64.39 \\
\hline DL-methionine & 0.05 & Calcium & 2.97 \\
\hline \multicolumn{2}{|c|}{ Feed additives used ( $\mathrm{g} / \mathrm{kg}$ of diet) } & Available phosphorus & 0.42 \\
\hline Biocholine & 0.50 & Metabolisable energy $^{*}(\mathrm{Kcal} / \mathrm{kg})$ & 2751.25 \\
\hline Biobantox & 0.50 & Lysine $^{*}$ & 0.84 \\
\hline Layvit & 0.50 & Methionine $^{*}$ & 0.34 \\
\hline Livoline & 0.25 & Zinc & $29.80 \mathrm{ppm}$ \\
\hline E-sel-powder & 0.10 & & \\
\hline K-zyme & 0.50 & & \\
\hline
\end{tabular}

${ }^{\#}$ Mineral mixture — without zinc, ${ }^{*}$ Calculated value. 
digesting of $0.5 \mathrm{~g}$ samples at $120^{\circ} \mathrm{C}$ using $5 \mathrm{ml}$ concentrate $\mathrm{HNO}_{3}$ for 1 hour using KEL plus digestion system. The digested samples were cooled and further digested with $30 \% \mathrm{H}_{2} \mathrm{O}_{2}$ at $200^{\circ} \mathrm{C}$. The process continued until the content appeared clear and colourless. At 35, 39, 43 and 48 weeks of experiment, $5 \mathrm{ml}$ of blood was drawn from the brachial vein of 12 birds per treatment (4 per replicate). The serum was obtained by centrifugation of coagulated blood at $700 \times \mathrm{g}$ for $5 \mathrm{~min}$. The serum were frozen at $-20^{\circ} \mathrm{C}$ until needed for analysis.

\subsection{Measure of Immunity}

\subsubsection{Cellular Immunity}

At 48 weeks of age, three birds from each replicate in each dietary treatment were injected intra-dermally in the right wattle with 100 micro gram of Phytohaemaglutinin-P (PHP-P) in $0.1 \mathrm{ml}$ of normal saline to measure the cellular immune response by Cutaneous Basophillc Hyper Sensitivity (CBH) test [15]. The thickness of wattle was measured using digital calliper before inoculation and $24 \mathrm{~h}$ post inoculation and CBH response was calculated using the formula:

$$
\mathrm{CBH} \text { response }=\frac{\text { Post-injection skin thickness }}{\text { Pre-injection thickness }} \times 100
$$

\subsubsection{Humoral Immunity}

The measure of humoral immunity was carried out as per the method described by [16]. Sheep red blood cells (SRBC) were used as test antigens to quantitatively analyse specific antibody response as measure of humoral immunity. At 48 weeks of age, three birds from each replicate in each dietary treatment were immunized intravenously via a wing vein with $0.07 \mathrm{ml}$ packed $\mathrm{RBC}$ mixed with $0.93 \mathrm{ml}$ physiological saline $(0.9 \% \mathrm{NaCl})$ for measure primary response. Seven days following the antigen challenge, blood samples were collected and serum samples were used to measure humoral immunity. Antibody production to SRBC was measured using micro titration hemmagglutination technique with micro titer plate $U$ shape of 96 wells ( 8 rows $\times 12$ column) according $[17,18]$. All SRBC antibody titers were expressed as $\log _{2}$ of the reciprocal of the highest serum dilution causing agglutination of SRBC.

\subsection{Collection of Faeces}

The faeces of the experimental broiler breeder birds were collected at 35, 39, 43 and 48 weeks of age. Three birds form each replicate of each group were taken for individual collection of faeces. A polythene sheet was attached under the cages of the birds and light was turn off for 1 hour. The faeces were homogeneously mixed replicate wise and representative samples of the faeces were collected in moisture cup and were oven dried at $105^{\circ} \mathrm{C}$ for $24 \mathrm{~h}$. For determination of zinc content in faeces, $2 \mathrm{gm}$ faecal samples were taken in a digestion tube and to it 12 $\mathrm{ml}$ of tri acid mixture $\left(7 \mathrm{ml} \mathrm{HNO}_{3}, 3 \mathrm{ml} \mathrm{H}_{2} \mathrm{SO}_{4}\right.$ and $2 \mathrm{ml}$ Perchloric acid) were added and digested at $200^{\circ} \mathrm{C}$.

\subsection{Statistical Analysis}

Data retrieved from the experiment was subjected to statistical analysis wherever required. The statistical analysis of the data was done according to [19].

\section{Results and Discussion}

\subsection{Immunity}

The effect of various levels of organic zinc on immune response of broiler breeders is presented in Table 2. The cellular immune response of breeder birds to PHA-P was significantly higher in higher zinc fed groups with $\mathrm{T}_{3}$ recorded highest response. The influence on primary antibody titer to SRBC was significantly $(\mathrm{P}<0.05)$ lower in $\mathrm{T}_{0}$ group (inorganic zinc) than that of other three organic zinc fed groups. [20] reported that immune response to PHA-P injection was enhanced when dietary zinc supplementation was solely from $\mathrm{ZnAA}$. They reported that PHA-P (mm) was 0.97 in $\mathrm{ZnSO}_{4}$ group and 1.12 in $\mathrm{ZnAA}$ group and they observed significant difference between these two groups. [21] reported that zinc as zinc-methionine supplementation $(100 \mathrm{mg} / \mathrm{kg}$ zinc to a basal diet containing $36.8 \mathrm{mg} / \mathrm{kg}$ zinc) had better effect on primary immune response to SRBC relative to control. Researcher has demonstrated supplementing broiler breeder hen diets with zinc-methionine rather than inorganic zinc sources increased cellular immune response of progeny to PHA-P [22]. [23] concluded that supplementation of $20 \mathrm{ppm}$ zinc significantly improved immune response and impact was more prominent with $\mathrm{ZnAA}$ (organic zinc) compared to $\mathrm{ZnSO}_{4}$. The broiler breeder hens provided diets supplemented with zinc from zinc amino acid which might have increased thymulin activity; therefore, enhancing immune response through increased maturation of T-lymphocyte and activation of B lym-

Table 2. Effect on immune response of broiler breeders in different dietary treatments of zinc.

\begin{tabular}{ccccc}
\hline Parameters & $\mathrm{T}_{0}$ & $\mathrm{~T}_{1}$ & $\mathrm{~T}_{2}$ & $\mathrm{~T}_{3}$ \\
\hline $\mathrm{CBH}$ & $165.89^{\mathrm{c}} \pm 10.98$ & $192.66^{\mathrm{c}} \pm 6.023$ & $243.96^{\mathrm{b}} \pm 7.76$ & $291.48^{\mathrm{a}} \pm 12.49$ \\
SRBC & $4.33^{\mathrm{b}} \pm 0.40$ & $5.88^{\mathrm{a}} \pm 0.30$ & $6.22^{\mathrm{a}} \pm 0.52$ & $6.44^{\mathrm{a}} \pm 0.68$ \\
\hline
\end{tabular}

Means with different superscripts in a row differ significantly $(\mathrm{P}<0.05)$. 
phocytes by T-helper cells [20]. Moreover, zinc has been shown to directly influence the immune system [24]. This element is required for normal immune function [25].

In contrast to this finding, [26] reported that zinc supplementation $\left(80 \mathrm{mg} / \mathrm{kg}\right.$ zinc from $\left.\mathrm{ZnSO}_{4}\right)$ had lower effect on primary immune response to SRBC relative to control. Similarly, [1] reported that on feeding of zinc both from inorganic and organic sources did not have any significant effect on either cellular or humoral immunity. Also, [27] reported that supplementation of zinc methionine partially or completely in place of inorganic sources had no much influence on primary antibody titer to SRBC

The weight of lymphoid organs (spleen and bursa) and liver of female broiler breeder of different dietary treatment has been presented in Table 3. The Weight lymphoid organs of different treatment groups (both organic and inorganic zinc fed groups) of the broiler breeders did not differ significantly $(P>0.05)$. [27] reported that dietary addition of organic zinc in place of inorganic source in broiler diet increased the relative weight of thymus as a proportion of live body weight but no significant effect on the weight of spleen and bursa of fabricius. [28] in their experiments in broiler reported that all the immune organs (bursa of fabricius, spleen and thymus) were significantly affected by the level of zinc-glycine in the diet at 21 day of age but at 42 day, no significant improvement in these organs were observed except for thymus. In contrast to this finding, [29] observed significant higher weight of spleen in zinc-proteanate group than the control group. Supplementation of zinc did not improve the weight of the lymphoid organs as more nutrients being reprationed to develop body weight and production and immune system need a small amount of nutrient in relation to what is needed for growth and production [30]. The weight of the liver (percentage of body weight) increased from $T_{0}$ to $T_{3}$ with significant lower liver weight was recorded in $T_{0}$ group. This might be due to numerical higher body weight of birds in $T_{3}$ than that of $T_{0}$ group.

\subsection{Bioavailability}

Measuring the deposition or storage of minerals in selected tissues (tibia or plasma zinc, liver copper and tibia manganese) is most common output in trace mineral relative bioavailability experiments [31]. Tissue mineral concentrations are indicators of body storage and mineral status and have been used as biomarker in requirement and bioavailability study [32]. According to some authors [33] and the opinion of Scientific Committee for Animal Nutrition on use of zinc of feeding stuffs, a clear indication of biological activity of zinc are: the content of this element in liver, melethionine activity, accumulation of zinc in the bones and levels of zinc in blood serum are the method of estimation of availability of this element in live animals.

The zinc content in the serum of broiler breeder in different dietary treatment during the experimental period is presented in Table 4. The zinc content of serum of broiler breeders of all the groups did not differed significantly in all the periods of study. No increasing or decreasing trend was observed even on feeding higher le-

Table 3. Weight lymphoid organs and liver (percentage of live weight) of broiler breeders in different dietary treatments of zinc.

\begin{tabular}{cccccc}
\hline Immune organ & $\mathrm{T}_{0}$ & $\mathrm{~T}_{1}$ & $\mathrm{~T}_{2}$ & $\mathrm{~T}_{3}$ & $\mathrm{P}$ value \\
\hline Spleen & $1.73 \pm 0.15$ & $1.82 \pm 0.12$ & $1.98 \pm 0.13$ & $2.15 \pm 0.17$ & 0.21 \\
Liver & $2.42^{\mathrm{c}} \pm 0.14$ & $2.82^{\mathrm{cb}} \pm 0.18$ & $2.97^{\mathrm{b}} \pm 0.22$ & $3.60^{\mathrm{a}} \pm 0.19$ & $<0.01$ \\
Bursa & $0.14 \pm 0.04$ & $0.12 \pm 0.02$ & $0.14 \pm 0.03$ & $0.17 \pm 0.04$ & 0.72 \\
\hline
\end{tabular}

Means with different superscripts in a row differ significantly $(\mathrm{P}<0.05)$.

Table 4. Zinc content (ppm) of serum of broiler breeders in different dietary treatments of zinc.

\begin{tabular}{cccccc}
\hline Weeks & $\mathrm{T}_{0}$ & $\mathrm{~T}_{1}$ & $\mathrm{~T}_{2}$ & $\mathrm{~T}_{3}$ & P value \\
\hline 35 week & $11.06 \pm 0.45$ & $10.58 \pm 0.31$ & $11.29 \pm 0.25$ & $11.27 \pm 0.30$ & 0.42 \\
39 weeks & $11.15 \pm 0.36$ & $11.26 \pm 0.51$ & $11.81 \pm 0.52$ & $11.66 \pm 0.40$ & 0.70 \\
43 weeks & $12.04 \pm 0.47$ & $11.26 \pm 0.35$ & $11.76 \pm 0.54$ & $12.24 \pm 0.50$ & 0.50 \\
48 week & $11.92 \pm 0.38$ & $12.10 \pm 0.34$ & $11.81 \pm 0.45$ & $12.58 \pm 0.44$ & 0.56 \\
Average & $11.54 \pm 0.21$ & $11.30 \pm 0.20$ & $11.67 \pm 0.22$ & $11.94 \pm 0.21$ & 0.21 \\
\hline
\end{tabular}

Means with different superscripts in a row differ significantly $(\mathrm{P}<0.05)$. 
vels of zinc in organic form or replacement of inorganic zinc with organic zinc in the diet of broiler breeders. [34] in their experiment on broilers reported that zinc content of serum of both organic and inorganic fed groups did not differ significantly which is in agreement with our finding. In contrast to this, [29] reported significantly higher level of serum zinc in zinc-proteanate group than control. Similarly, [35] reported that broiler chicken received diet containing zinc-methionine had increased level serum zinc compared to the content of this element in birds received zinc sulphate. The non-significant level of serum zinc in different periods of study might be due to mineral homeostasis which is precisely maintained in the body and is predominantly achieved by balancing tissue storage and excretion [36].

Zinc content in liver, tibia, kidney and spleen of broiler breeders in different dietary treatments is presented in Table 5. Zinc content in liver and tibia of broiler breeders in different dietary treatments of zinc differed significantly $(\mathrm{P}<0.05)$ with higher levels obtained on increasing zinc concentration in the diet. The increased level of zinc in tibia as observed in the present study is in agreement with the findings of $[29,34,35$, $37,38]$. In contrast to this finding, [39] reported dietary treatment by replacing $50 \%$ of the inorganic $\mathrm{Zn}, \mathrm{Cu}, \mathrm{Mn}$ in the control ration with chelated minerals at 14 and 52 day, there was no significant difference between the control and treatment group for tibia zinc content. This might be due to lower duration of feeding. [26] reported that feeding broiler chicken with feed containing either zinc-methionine or $\mathrm{ZnO}$ had no significant effect on the presence of microelements in the bone. Moreover, based on tibia zinc content, [11] reported that zinc from zinc methionine, is more bio-available than zinc from $\mathrm{ZnSO}_{4}$ or $\mathrm{ZnO}$. Similarly, [9] reported the impact of different dietary concentrations of minerals on their deposition rate in tibia. Their results showed that with feeding different diets containing same concentration of zinc, manganese and copper, birds were able to deposit organic form of minerals more efficient than their inorganic form.

[37] reported that the increased dietary addition of zinc from both organic and inorganic sources increased the liver zinc content. [40] reported that on supplementation of $100 \mathrm{ppm}$ zn-methionine chelate over the NRC level in control group exhibited higher zinc content in the liver $(104.53 \mathrm{ppm})$ of zinc-methionine supplemented group than control $(99.50 \mathrm{ppm})$ in spite of any significant difference between the two groups. In support to our finding, [26] reported that feeding broiler chicken with feed containing either zinc-methionine or $\mathrm{ZnO}$ had no significant effect on the presence of microelements in the liver and pancreas at the same level of feeding but they observed significant difference in zinc levels of those organs at different levels of feeding.

The zinc level in the spleen and kidney of the broiler breeders in different dietary treatments did not differ significantly. No such reported work was available on this study. Probably, the weight of immune organ have significance in birds on feeding different source and level of zinc rather than the level of zinc in those organs.

\subsection{Faecal Excretion}

The zinc content in the faeces of broiler breeder in different dietary treatment during the experimental period has been presented in Table 6. The zinc content in the faeces (excretion) of broiler breeders in different dietary treatments of zinc did not differ significantly among all the treatments during the periods of study viz. $32-35$ weeks, 36 - 39 weeks and 40 - 43 weeks of age. Even the zinc level was higher in $T_{3}$ and $T_{2}$ but the zinc excretion was not significant which implied better bioavailability of organic zinc. [41] reported that one of the benefits of feeding chelated minerals to broilers was to improve mineral bioavailability, allowing reduction in dietary mineral supplementation and thus reduced excretion. Organically complexed trace minerals provide alternative pathways for absorption, thus leading to a reduction in the excretion of minerals [42]. But during 44 - 48 weeks of age, the zinc excretion in faeces was significantly higher in $T_{3}$ than that of $T_{2}, T_{1}$ and $T_{0}$ groups. The overall zinc excretion in faeces of $T_{3}$ did not differ significantly with $\mathrm{T}_{2}$ which implied higher retention of zinc in $\mathrm{T}_{3}$ as it contained $20 \mathrm{ppm}$ which is more organic zinc

Table 5. Zinc content (ppm) in organs and chicks of broiler breeders in different dietary treatments of zinc.

\begin{tabular}{cccccc}
\hline Organs & $\mathrm{T}_{0}$ & $\mathrm{~T}_{1}$ & $\mathrm{~T}_{2}$ & $\mathrm{~T}_{3}$ & $\mathrm{P}$ value \\
\hline Liver & $75.76^{\mathrm{c}} \pm 2.28$ & $83.37^{\mathrm{bc}} \pm 3.29$ & $90.92^{\mathrm{b}} \pm 3.27$ & $106.12^{\mathrm{a}} \pm 3.065$ & $<0.01$ \\
Kidney & $91.65 \pm 1.184$ & $89.85 \pm 0.82$ & $90.51 \pm 0.89$ & $92.73 \pm 0.74$ & 0.15 \\
Spleen & $85.62 \pm 1.43$ & $82.33 \pm 1.68$ & $84.89 \pm 2.51$ & $85.69 \pm 1.72$ & 0.56 \\
Tibia & $203.0^{\mathrm{c}} \pm 9.54$ & $320.81^{\mathrm{b}} \pm 16.71$ & $375.22^{\mathrm{a}} \pm 12.98$ & $381.84^{\mathrm{a}} \pm 13.99$ & $<0.01$ \\
chick & $55.25^{\mathrm{d}} \pm 1.51$ & $59.38^{\mathrm{c}} \pm 1.37$ & $65.6^{\mathrm{b}} \pm 1.43$ & $71.81^{\mathrm{a}} \pm 0.97$ & $<0.01$ \\
\hline
\end{tabular}

Means with different superscripts in a row differ significantly $(\mathrm{P}<0.05)$. 
Table 6. Zinc content (ppm) in the faeces (excretion) of broiler breeders in different dietary treatments of zinc.

\begin{tabular}{cccccc}
\hline Weeks & $\mathrm{T}_{0}$ & $\mathrm{~T}_{1}$ & $\mathrm{~T}_{2}$ & $\mathrm{~T}_{3}$ & P value \\
\hline 35 Week & $119.24 \pm 2.98$ & $118.55 \pm 2.43$ & $122.88 \pm 3.079$ & $127.81 \pm 2.24$ & 0.08 \\
39 weeks & $124.74 \pm 2.57$ & $126.33 \pm 2.76$ & $133.58 \pm 2.002$ & $129.36 \pm 2.99$ & 0.10 \\
43 weeks & $119.81 \pm 2.42$ & $124.88 \pm 2.47$ & $126.85 \pm 2.41$ & $125.80 \pm 1.45$ & 0.14 \\
48 week & $120.01^{\mathrm{c}} \pm 2.16$ & $122.25^{\mathrm{c}} \pm 1.91$ & $128.47^{\mathrm{b}} \pm 1.37$ & $137.79^{\mathrm{a}} \pm 1.32$ & $<0.01$ \\
Average & $120.95^{\mathrm{b}} \pm 1.27$ & $123.008^{\mathrm{b}} \pm 1.26$ & $127.95^{\mathrm{a}} \pm 1.27$ & $130.19^{\mathrm{a}} \pm 1.27$ & $<0.01$ \\
\hline
\end{tabular}

Means with different superscripts in a row differ significantly $(\mathrm{P}<0.05)$.

than that of $\mathrm{T}_{2}$. This implied that in the $20 \mathrm{ppm}$ organic zinc group where the diet contained $60 \mathrm{ppm}$ of total zinc as compared to $40 \mathrm{ppm}$ in control group, the bioavailability was significantly improved as the faecal loss in both groups were comparable. [43] fed broilers with basal diet contained $30 \mathrm{mg} / \mathrm{kg}$ zinc in control and added inorganic zinc at the levels of 20, 40, $80 \mathrm{mg} / \mathrm{kg}$. Similarly organic zinc was added to other groups at the levels of 20 , $40,80 \mathrm{mg} / \mathrm{kg}$. They reported that neither in $\mathrm{ZnSO}_{4}$ or organic alone supplemented groups, there was a reduction in zinc excretion. But they observed significantly lower zinc excretion in both organic and inorganic supplemented group. They also reported that the cumulative zinc excretion of organic zinc fed groups were significantly lower than inorganic zinc fed groups. [44] reported that the total amount of inorganic minerals in a broiler premix could be totally replaced by $20 \%$ organic minerals without affecting growth performance and at the same time reducing environmental pollution. [45] reported that organic minerals that are chelated to small peptides have much greater bioavailability through increased selective transport of peptide at gut level. Enhanced bioavailability of mineral source can potentially reduce the amount of a mineral that is added to a diet to meet nutritional requirement, leading to reduced amount of mineral excreted by birds [46].

\section{REFERENCES}

[1] M. T. Kidd, N. B. Anthony and S. R. Lee, "Progeny Performance When Dams and Chicks Are Fed Supplemental Zinc," Poultry Science, Vol. 71, No. 7, 1992, pp. 12011206. http://dx.doi.org/10.3382/ps.0711201

[2] M. P. Fletcher, M. E. Gershwin, C. L. Keen and L. S. Hurley, "Trace Element Deficiencies and Immune Responsiveness in Human and Animal Models," In: R. K. Chandra, Ed., Nutrition and Immunology, Alan Liss, New York, 1988, pp. 215-239.

[3] P. J. Fraker, L. E. King and T. Laakko, "The Dynamic Link between the Integrity of the Immune System and Zinc Status," Journal of Nutrition, Vol. 130, 2000, pp. 1399-1406.

[4] R. W. Luecke, C. E. Simonel and P. J. Fraker, "The Ef- fect of Restricted Dietary Intake on the Antibody Mediated Response of the Zinc Deficient A/J Mouse," Journal of Nutrition, Vol. 108, No. 5, 1978, pp. 881-887.

[5] J. D. Flinchum, C. F. Nockels and R. E. Moreng, "Aged Hens Fed Zinc-Methionine Had Chicks with Improved Performance," Poultry Science, Vol. 68, Suppl. 1, 1989, p. 55.

[6] P. J Fraker, M. E. Gershwin, R. A. Good and A. Prasad, "Interrelationships between Zinc and Immune Function," Federation Proceedings, Vol. 45, No. 5, 1986, pp. 1474 1478.

[7] P. L. Hooper, L. Visconti, P. J. Garry and G. E. Johnson, "Zinc Lowers High-Density Lipoprotein-293 Cholesterol Levels," Journal of American Medical Association, Vol. 244, No. 17, 1980, pp. 1960-1961. http://dx.doi.org/10.1001/jama.1980.03310170058030

[8] W. W. Gill, "Optimum Mineralization of the Beef Herd," University of Tennessee Agricultural Extension Service Publication, USA, 2000.

[9] A. Gheisari, R.-F. Ali, T. Ali and M. M. Gheisari, "Effect of Organic Chelates of Zinc, Manganese and Copper in Comparison to Their Inorganic Sources on Performance of Broiler Chickens," Journal of Animal and Plant Sciences, Vol. 6, No. 2, 2010, pp. 630-636.

[10] D. H. Baker and C. B. Ammerman, "Copper Bioavailability," In: C. B. Ammerman, D. H. Baker and A. J. Lewis, Ed., Bioavailability of Nutrients for Animals, Amino Acids, Minerals and Vitamins, Academic Press, San Diego, 1995, pp. 127-156. http://dx.doi.org/10.1016/B978-012056250-3/50034-2

[11] K. J. Wedekind, A. E. Hortin and D. H. Baker, "Methodology for Assessing Zinc Bioavailability: Efficiency Estimates for Zinc-Methionine, Zinc Sulphate and Zinc Oxide," Journal of Animal Science, Vol. 70, No. 4, 1992, pp. 178-187.

[12] BIS, "Poultry Feed Specifications," 4th Review, Bureau of Indian Standards, Manak Bhawan, New Delhi, 1992.

[13] AOAC, "Official Methods of Analysis," 16th Edition, Association of Official Analytical Chemists, Arlington, 1995.

[14] B. Panda and S. C. Mohapatra, "Bleeding of Poultry Modified by Kosher's Method," Poultry Production, ICAR publication, New Delhi, 1989, p. 121.

[15] A. S. Edelman, P. I. Sachez, M. E. Robinson, G. M. Hochwalad and G. J. Thorbecke, "Primary and Secondary 
Swelling Response to Phytohaemagglutinin as a Measure of Immune Competence in Chickens," Avian Diseases, Vol. 30, No. 10, 1986, pp. 105-111. http://dx.doi.org/10.2307/1590619

[16] A. G. Abdallah, O. M. El-Husseiny and K. O. Abdel-Latif, "Influence of Some Dietary Organic Mineral Supplementations on Broiler Performance," International Journal of Poultry Science, Vol. 8, No. 3, 2009, pp. 291-298. http://dx.doi.org/10.3923/ijps.2009.291.298

[17] S. E. Bachman and M. M. Mashaly, "Relation between Circulating Thyroid Hormones and Humoral Immunity in Immature Male Chicken's," Developmental and Comparative Immunology, Vol. 10, No. 2, 1986, pp. 395-399. http://dx.doi.org/10.1016/0145-305X(86)90029-7

[18] O. H. Kai, N. Nagase, M. Ishikawa, K. Suzuki and K. Sato, "Effects Propylthiouracial (PTU) on the Immunological Status of the Chickens," Developmental and Comparative Immunology, Vol. 12, No. 1, 1988, pp. 145-156. http://dx.doi.org/10.1016/0145-305X(88)90032-8

[19] G. W. Snedecor and W. G. Cochran, "Statistical Methods," 8th Edition, Iowa State University Press, Ames, 1989.

[20] B. P. Hudson, W. A. Dozier, J. L. Wilson, J. E. Sander and T. L. Ward, "Reproductive Performance and Immune Status of Caged Broiler Breeder Hens Provided Diets Supplemented with Either Inorganic or Organic Sources of Zinc from Hatchery to 65 wk of Age," Journal of Applied Poultry Science, Vol. 13, No. 2, 2004, pp. 49-59.

[21] J. L. Stahl, M. E. Cook, M. L. Sunde and J. L. Greger, "Enhanced Humoral Immunity in Progeny Chicks from Hens Fed Practical Diets Supplemented with Zinc," Applied Agricultural Research, Vol. 4, No. 2, 1989, pp. 8689.

[22] W. S. Virden, J. B. Yeatman, S. Barber, K. O. Willeford, T. L. Ward, T. M. Fakler, R. F. Wideman and M. T. Kidd, "Immune System and Cardiac Functions of Progeny Chicks from Dams Fed Diets Differing in Zinc and Manganese Level and Source," Poultry Science, Vol. 83, No. 3, 2004, pp. 344-351.

[23] P. Shinde, R. S. Dass, A. K. Chaturvedi and R. Kumar, "Effect of Zinc Supplementation from Different Sources on Growth, Nutrient Digestibility, Blood Metabolic Profile and Immune Response of Male Guinea Pigs," Biological Trace Element Research, Vol. 112, No. 3, 2006, pp. 247-262. http://dx.doi.org/10.1385/BTER:112:3:247

[24] M. Kirchgessner, "Underwood Memorial Lecture. Homeostasis and Homeorhesis in Trace Element Metabolism," In: M. Anke, D. Meissner and C. F. Mills, Eds., Trace Elements in Man and Animals, Vol. 8, Verlag Media Touristik Dresden, Germany, 1993, pp. 4-21.

[25] M. T. Kidd, P. R. Ferket and M. A. Qureshi, "Zinc Metabolism with Especial Reference to Its Role in Immunity," World Poultry Science Journal, Vol. 52, No. 3, 1996, pp. 309-324.

http://dx.doi.org/10.1079/WPS19960022

[26] J. L. Pimentel, M. E. Cook and J. L. Greger, "Bioavailability of Zinc-Methionine for Chicks," Poultry Science, Vol. 70, No. 4, 1991, pp. 1637-1639.

http://dx.doi.org/10.3382/ps.0701637
[27] H. N. Moghaddam and R. Jahanian, "Immunological Responses of Broiler Chicks Can Be Modulated by Dietary Supplementation of Zinc-Methionine in Place of Inorganic Zinc Sources," Asian-Australian Journal of Animal Science, Vol. 22, No. 3, 2009, pp. 396-403.

[28] J. Feng, W. Q. Ma, H. H. Niu, X. M. Wu, Y. Wang and J. Feng, "Effects of Zinc Glycine Chelate on Growth, Hematological and Immunological Characteristics in Broilers," Biological Trace Element Research, Vol. 133, No. 1, 2001, pp. 203-211.

[29] O. M. O. Idowu, R. O. Ajuwon, A. O. Osoand and A. O. Akinloye, "Effect of Zinc Supplementation on Laying Performance, Serum Chemistry and Zn Residue in Tibia Bone, Liver, Excreta and Egg Shell of Laying Hens," International Journal of Poultry Science, Vol. 10, No. 3, 2011, pp. 225-230.

http://dx.doi.org/10.3923/ijps.2011.225.230

[30] J. R. Bartlett and M. O. Smit, "Effect of Different Levels of Zinc on the Performance and Immuno Competence of Broilers under Heat Stress," Poultry Science, Vol. 82, No. 10, 2003, pp. 1580-1588.

[31] E. J. Underwood and N. F. Suttle, "The Mineral Nutrition of Livestock," 3rd Edition, CABI Publishing, Wallingford, 1999, p. 497.

http://dx.doi.org/10.1079/9780851991283.0000

[32] F. Yan and P. W. Waldroup, "Evaluation of Mintrex Manganese as a Source of Manganese for Young Broiler," International Journal of Poultry Science, Vol. 5, No. 8, 2006, pp. 708-713.

http://dx.doi.org/10.3923/ijps.2006.708.713

[33] S. Aoyagi and D. H. Baker, "Nutritional Evaluation of Copper-Lysine and Zinc-Lysine Complexes for Chicks," Poultry Science, Vol. 72, No. 1, 1983, pp. 161-171.

[34] W. Tronina, S. Kinaland and B. Lubojemska, "Effect of Various Forms of Zinc Applied in Concentrate Mixtures for Broiler Chickens on Its Bioavailability as Well as Meat Composition and Quality," Poland Journal of Food and Nutrition Science, Vol. 57, No. 4, 2007, pp. 577-581.

[35] B. Dolęgowska, Z. Machoy and D. Chlubek, "Changes in the Content of Zinc and Fluoride during Growth of the Femur in Chicken," Biological Trace Element Research, Vol. 91, No. 4, 2003, pp. 67-76. http://dx.doi.org/10.1385/BTER:91:1:67

[36] E. Underwood and N. F. Suttle, "The Mineral Nutrition of Livestock," CABI Publishing, London, 2001.

[37] T. Ao, J. L. Pierce, R. Power, K. A. Dawson, A. J. Pescatore, A. Cantor and M. J. Ford, "Evaluation of Bioplex Zn as an Organic Zinc Sources for Chicks," International Journal of Poultry Science, Vol. 5, No. 9, 2006, pp. 808811. http://dx.doi.org/10.3923/ijps.2006.808.811

[38] J. Cao, P. R. Henry, R. Guo, R. A. Holwerda, J. P. Toth, R. C. Littell, R. D. Miles and C. B. Ammerman, "Chemical Characteristics and Relative Bioavailability of Supplemental Organic Zinc Sources for Poultry and Ruminants" Journal of Animal Science, Vol. 78, No. 8, 2000, pp. 2039-2054.

[39] J. Zhao, R. B. Shirley, M. Vazquez-Anon, J. J. Dibner, J. D. Richards, P. Fisher, T. Hampton, K. D. Christensen, J. P. Allard and A. F. Giesen, "Effect of Chelated Trace 
Minerals on Growth Performance, Breast Meat Yield, and Footpad Health in Commercial Meat Broiler," Journal of Applied Poultry Research, Vol. 19, No. 4, 2010, pp. 365372. http://dx.doi.org/10.3382/japr.2009-00020

[40] H. S. Lim and Paik, "Effect of Supplementary Mineral Methionine Chelates ( $\mathrm{Zn}, \mathrm{Cu}, \mathrm{Mn})$ on the Performance and Egg Shell Quality of Laying Hens," Asian-Australian Journal of Animal Science, Vol. 16, No. 12, 2003, pp. 1804-1808.

[41] W. A. Dozier, A. J. Davis, M. E. Freeman and T. L. Ward, "Zinc and Copper Excretion of Broiler Chicks Fed Gradient Concentrations of Zinc and Copper from Three Different Sources," Poultry Science, Vol. 81, Suppl. 1, 2002, pp. 141-145.

[42] S. Leeson, “A New Look at Trace Mineral Nutrition of Poultry: Can We Reduce the Environmental Burden of Poultry Manure?" In: T. P. Lyons and K. A. Jacques, Eds., Nutritional Biotechnology in the Feed and Food Industries, Proceedings of Alltech's 19th Annual Symposium, Nottingham University Press, Nottingham, 2003, pp. 125-
129.

[43] A. L. Burrell, W. A. Dozier, A. J. Davis, M. M. Compton, M. E. Freeman, P. F. Vendrell and T. L. Ward, "Responses of Broilers to Dietary Zinc Concentrations and Sources in Relation to Environmental Implications," British Journal of Poultry Science, Vol. 45, No. 4, 2011, pp. 255-263.

[44] A. Sacranie, "At the Cutting Edge," Asia-Pacific Poultry News Letter Alltech, Vol. 2, No. 3, 2003.

[45] T. Webb, K. E. Wong, Y. X. Pan, H. Chen, C. A. Poole, L. Van and J.E. Klang, "The Role of Peptides in Absorption Pathways in Redefining Mineral Nutrition," In: J. A. Taylore-Pickard and L. A. Tucker, Eds., Nottingham University Press, Nottingham, 2005, pp. 197-225.

[46] J. Cheng, E. T. B. Kornegay and T. Schell, "Influence of Dietary Lysine on the Utilization of Zinc from $\mathrm{ZnSO}_{4}$ and a Zinc-Lysine Complex by Young Pigs," Journal of Animal Science, Vol. 76, No. 4, 1998, pp. 1064-1074. 